\title{
Tennessee River Resource Stewardship and Protection: The Tennessee River Line Trail Project and Partnerships
}

\author{
Kenneth R. Olson \\ Soil Science in the College of Agricultural, Consumer, and Environmental Sciences, University of Illinois, Urbana, USA \\ Email: krolson@illinois.edu
}

How to cite this paper: Olson, K.R. (2020) Tennessee River Resource Stewardship and Protection: The Tennessee River Line Trail Project and Partnerships. Journal of Water Resource and Protection, 12, 1053-1076. https://doi.org/10.4236/jwarp.2020.1212063

Received: October 29, 2020

Accepted: December 11, 2020

Published: December 14, 2020

Copyright $\odot 2020$ by author(s) and Scientific Research Publishing Inc. This work is licensed under the Creative Commons Attribution International License (CC BY 4.0).

http://creativecommons.org/licenses/by/4.0/

\section{(c) (i) Open Access}

\begin{abstract}
The Tennessee River had a long and colorful history of transporting Native Americans, settlers, armies, and cargo of all types in 1700s and 1800s. The headwaters of the Tennessee River, the largest tributary of the Ohio River, originates in the Appalachian Mountains of eastern United States. Created by the confluence of the Holston and French Broad rivers at Knoxville, the Tennessee River flows approximately $1049 \mathrm{~km}$ to Paducah, Kentucky where it drains into the Ohio River. This paper highlights how the landscape and geological resources of the Tennessee River and tributaries watershed contributed to the successful economic development of this historical region of North America. The Tennessee River is one of the most biologically diverse freshwater systems in the United States. Environmental challenges included an unsuccessful attempt to keep invasive species, such as the Asian carp, out of the Tennessee River and the Kentucky Lake. The 1049 river kilometer Tennessee River regional trail system with charter River Towns was designed to promote recreational tourism, increase the use of the Tennessee River and to create generations of people who care about the river and are willing to provide environmental stewardship of the watershed resources and protect the river.
\end{abstract}

\section{Keywords}

Flood of 1937, Kentucky Dam, Kentucky Lake, Navigation, Big Head Carp, Silver Carp, Paducah, Kentucky, Tennessee Valley Authority, TVA

\section{Introduction}

The Cherokee Indians called the river "hogoheeggee" meaning "Big River" while 
Europeans called it "Old French Fork" and "River of the Cherokee" or Cherokee River [1]. By the $18^{\text {th }}$ century, it was known as the Tennessee River (Figure 1). Over millions of years, the river carved a path through the Appalachian escarpment in eastern Tennessee as it flowed southwest towards Chattanooga before crossing into Alabama [2]. Today the river cuts through steep forested hillsides and the grasslands of the central plains as it loops through northern Alabama and intersects three state borders (Mississippi, Alabama, Tennessee) before turning northward through Tennessee and Kentucky where it merges with the Ohio River at Paducah, Kentucky (Figure 2). Tennessee River is one of the few rivers that leaves a state, Kentucky, and then re-enters. The source elevation is

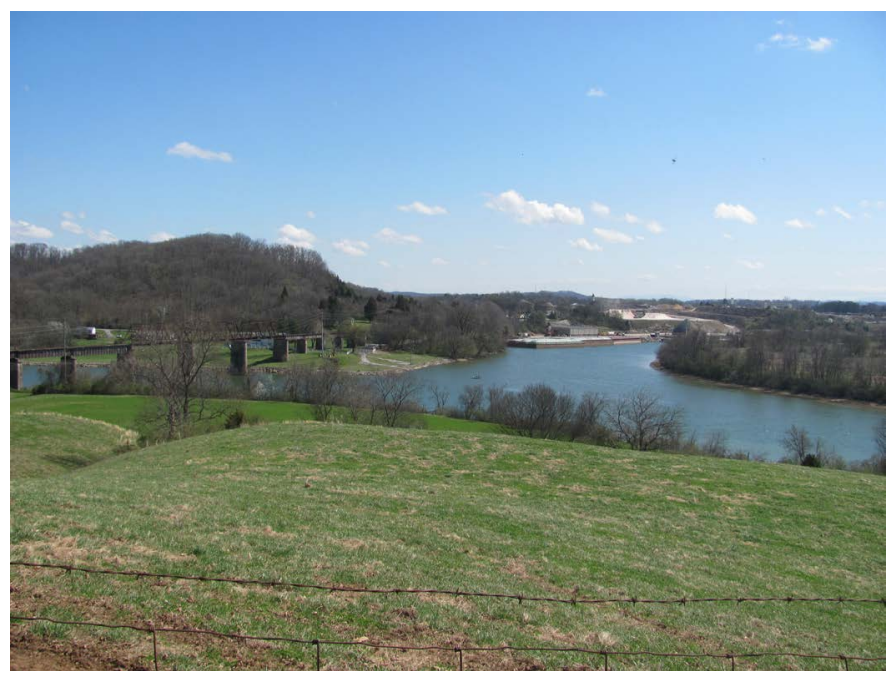

Figure 1. The Tennessee River begins at the confluence of the French Broad and Holston rivers near Knoxville, Tennessee.

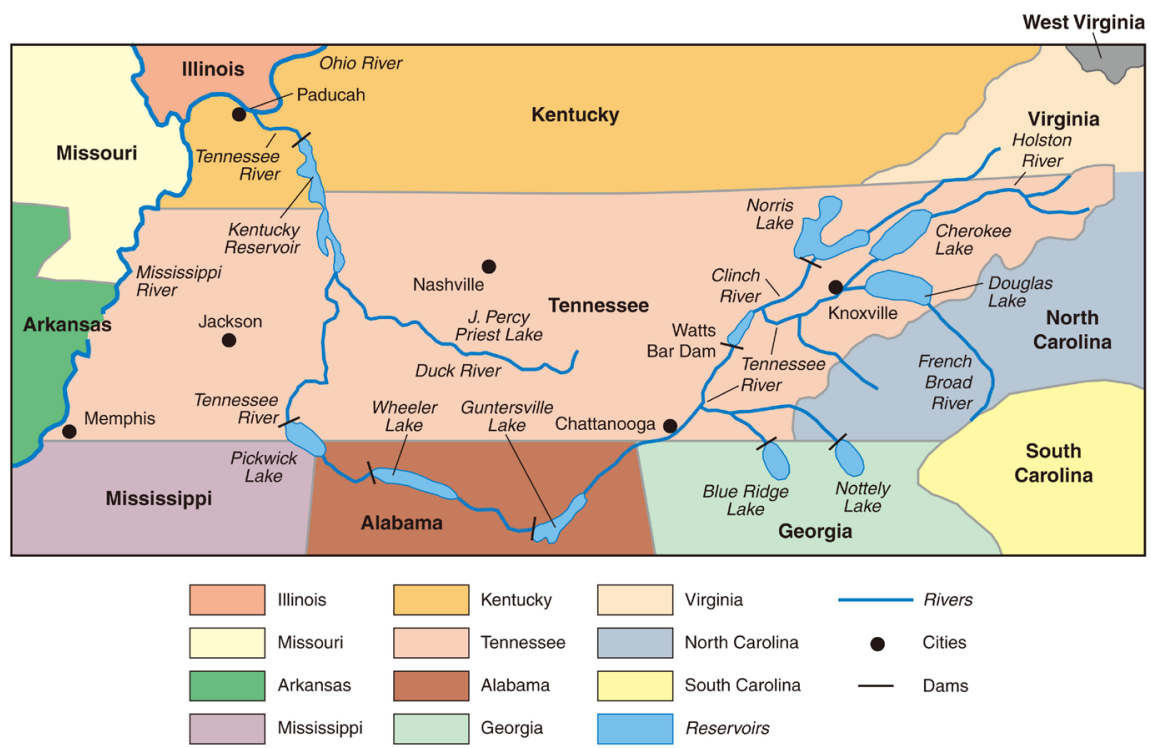

Figure 2. Modified map of Tennessee River basin [3] upland waters from seven states drain into the Ohio River at Paducah. Published with copyright permission from Book Editor of Soil and Water Conservation Society [3]. Map created by Mic Greenberg. 
$248 \mathrm{~m}$ and the discharge elevation is $92 \mathrm{~m}$ at the confluence of the Tennessee River and the Ohio River. The average Tennessee River discharge is $2000 \mathrm{~m}^{3} / \mathrm{s}$ and the watershed is $105,870 \mathrm{~km}^{2}$. Approximately 17,000 recreational boats travel each year along the river, which is used for pleasure and leisure as well as for-profit [2].

The Tennessee River was the western boundary for lands open to settlement until 1818 when the Jackson Purchase pushed the boundary and many Native Americans beyond the Mississippi River [1]. The endorsement of the 1830 Indian Removal Act by President Andrew Jackson forced the Seminole, Cherokee, Chickasaw, Muscogee, and Choctaw nations from their ancestral homelands in southeastern United States to designated Indian Territory west of the Mississippi River. The Tennessee River, part of the Trail of Tears (Figure 3 and Figure 4), was a key water route traversed by the Indians in a difficult and deadly $3200 \mathrm{~km}$ forced re-location trip west.

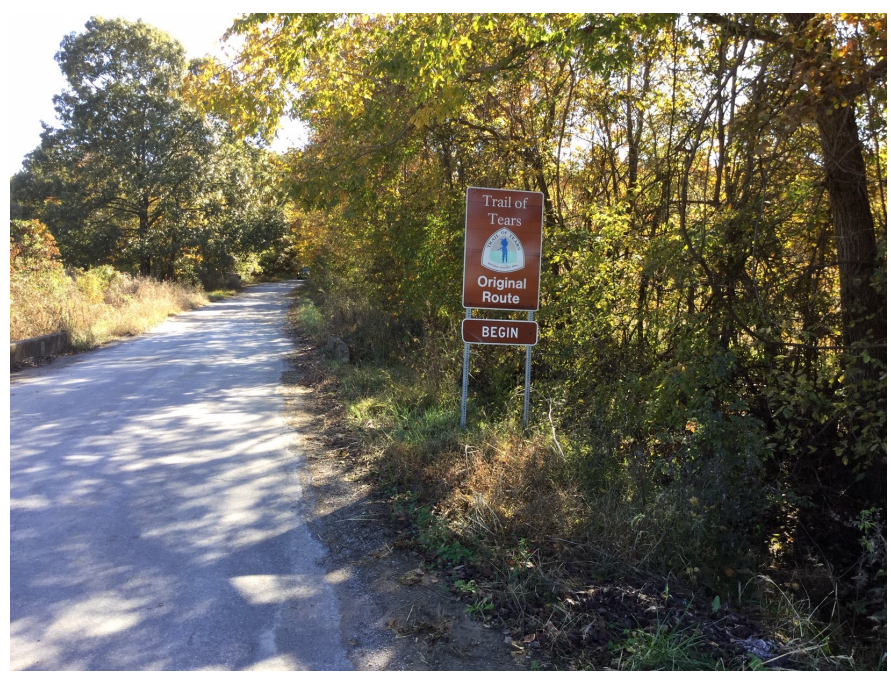

Figure 3. Trail of tears sign along the actually trail pathway.

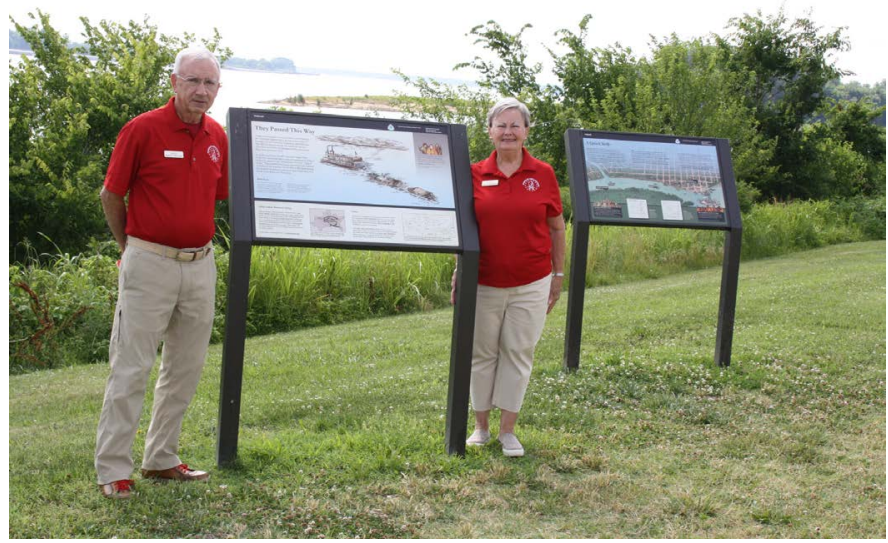

Figure 4. Paducah Ambassadors John and Cindy Crivello by information placards of the 1938 Trail of Tears Indian Removal. Picture taken by Theresa Simmons (Daughter of John and Cindy Crivello). 
The starting point of the Tennessee River as well as state land and water rights have been the subject of much debate. In 1890 a federal law declared the Tennessee River to begin where the Holston River and the French Broad River come together southeast of Knoxville, Tennessee (Figure 1). In 1796, when Tennessee was admitted to the Union, the border between Georgia and Tennessee was originally defined as the $35^{\text {th }}$ parallel, thereby ensuring that at least part of the river would be located in Georgia (Figure 2). As a result of an erroneous survey conducted in 1818 , the actual border was set $1.6 \mathrm{~km}$ south of $35^{\circ}$ latitude which placed the entire river in Tennessee. Georgia has made many attempts since the 1890 s to correct the erroneous survey line which resulted in significant Georgia land and population being in Tennessee. Eventually, if state negotiations continue to fail, the border issue could end up in the U.S. Supreme Court.

The primary objectives of the paper are: 1) To document how the landscape and geological resources of the Tennessee River have contributed to the successful water resource and economic development of a historically region in North America; 2) To identify the natural and environmental resource risks to the Tennessee River basin; 3) Document the Tennessee River regional trail system with the goal of creating more community access points along the 1049 river kilometer Tennessee River pathway; 4) To create generations of people who care about the environmental stewardship and protection of the river and landscape resources.

\section{Paducah, Kentucky Is at the Confluence of the Tennessee and Ohio Rivers}

Paducah, Kentucky was built on the southern banks of the Ohio River at the confluence with the Tennessee River (Figure 5). This port city (Figure 6), incorporated in 1830, became a thriving metropolis and transportation hub fueled by steamboat and towboat traffic and an expanding network of railroads hauling agricultural commodities, coal, iron ore and other raw materials (Figure 7) for manufacturing, steel and finished products to markets. Paducah was protected from river flooding by earthen levees during the 1884, 1913, and 1927 floods. However, these earthen levees were inadequate when in 1937 the Ohio River reached record levels and breached the levees flooding the entire Paducah downtown (Figure 8) [3] [4] [5].

Heavy precipitation from the Gulf of Mexico and a polar vortex from the northwest collided over the Ohio valley from Christmas 1936 into January 1937 (Figure 9) and dumped 151 billion metric tons-155 quadrillion liters of ice, snow, sleet and rain over a four week period [6]. In the third week of the storm, $18-25 \mathrm{~cm}$ of rain fell on the Tennessee, Cumberland and Wabash valleys breaking 1913 flood records throughout the Ohio valley. The following week a $4^{\text {th }}$ wave of storms dumped up to $36 \mathrm{~cm}$ of rain; and on January 21, 1937 the Ohio River at Paducah rose above the $15 \mathrm{~m}$ flood stage. The swollen Ohio River rushing south to Cairo, Illinois was a wall of water which blocked the Tennessee 


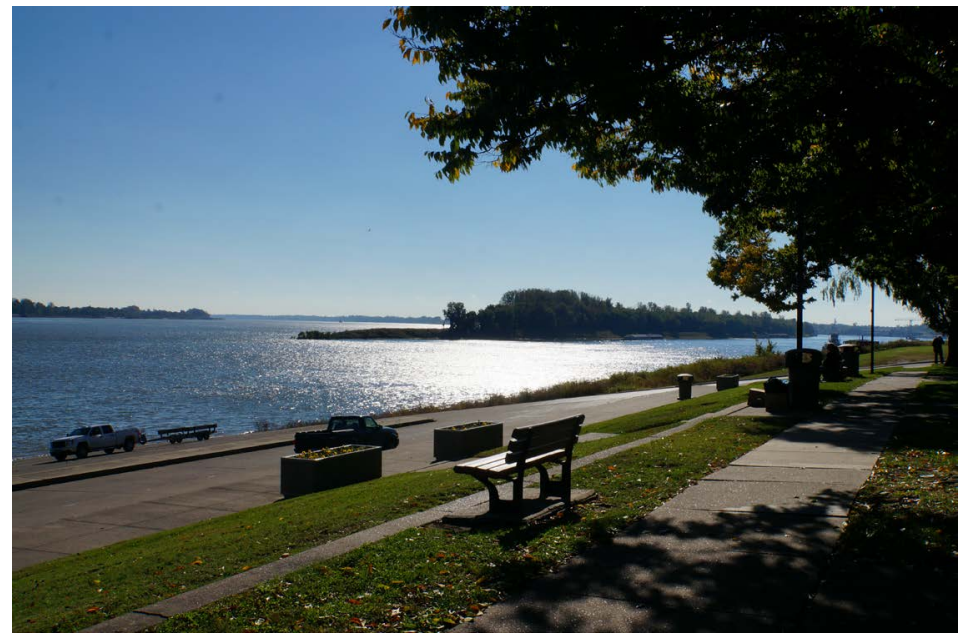

Figure 5. Confluence of the Ohio River (Mile 934) and the Tennessee River (Mile 0.0) at Paducah, Kentucky. The floodwall at Paducah, Kentucky constructed after the 1937 flood which destroyed most of downtown Paducah. Photograph by Lois Wright Morton.

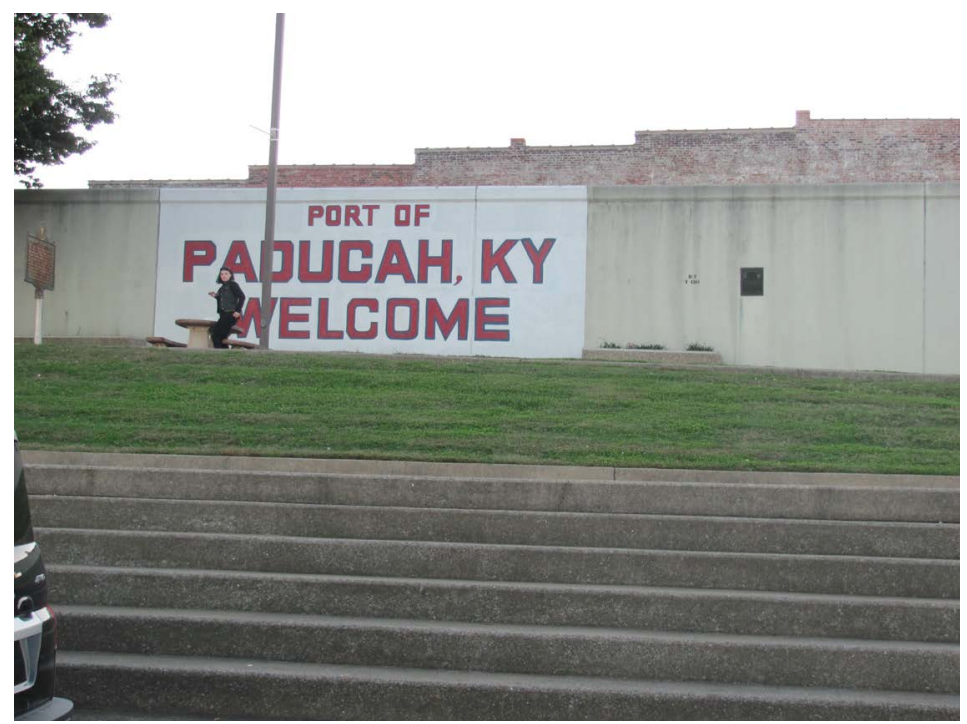

Figure 6. The river side of the floodwall at Paducah City Front during minor flood stage.

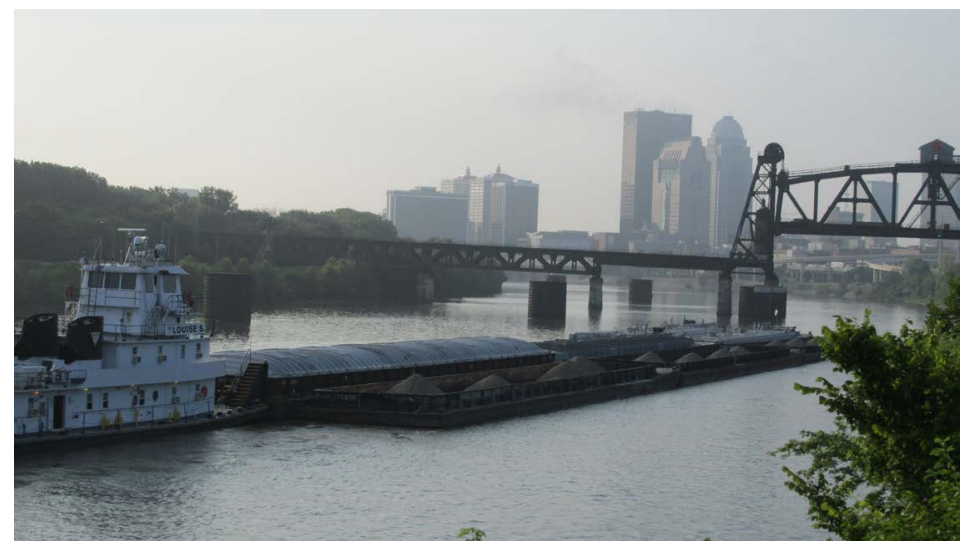

Figure 7. Tug boat pushing barges carrying raw materials up the Ohio River from Paducah to Pittsburgh. The city of Louisville is in the background. 


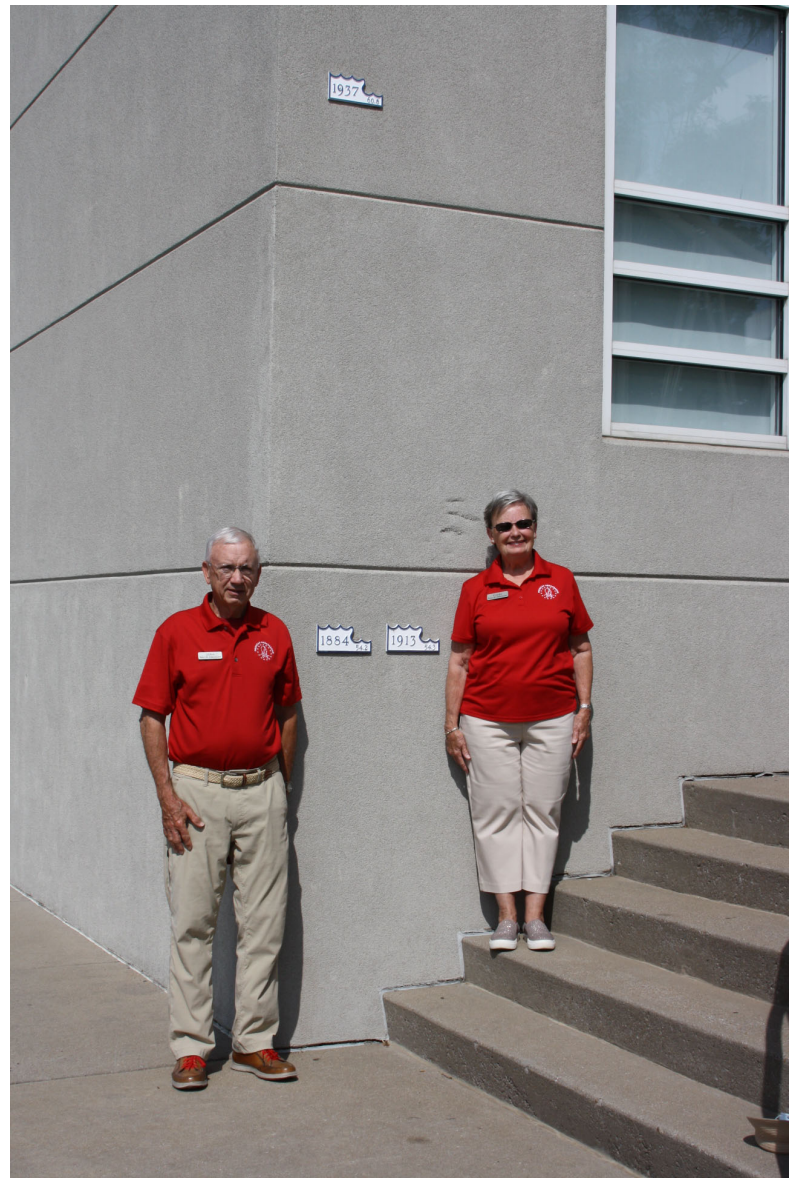

Figure 8. Paducah Ambassadors John and Cindy Crivello by flood level indicators for 1884, 1913, and 1937 on the Seamen's Church Center for Maritime Education Building at the corner of Kentucky Avenue and Water Street. Picture taken by Theresa Simmons (Daughter of John and Cindy Crivello).

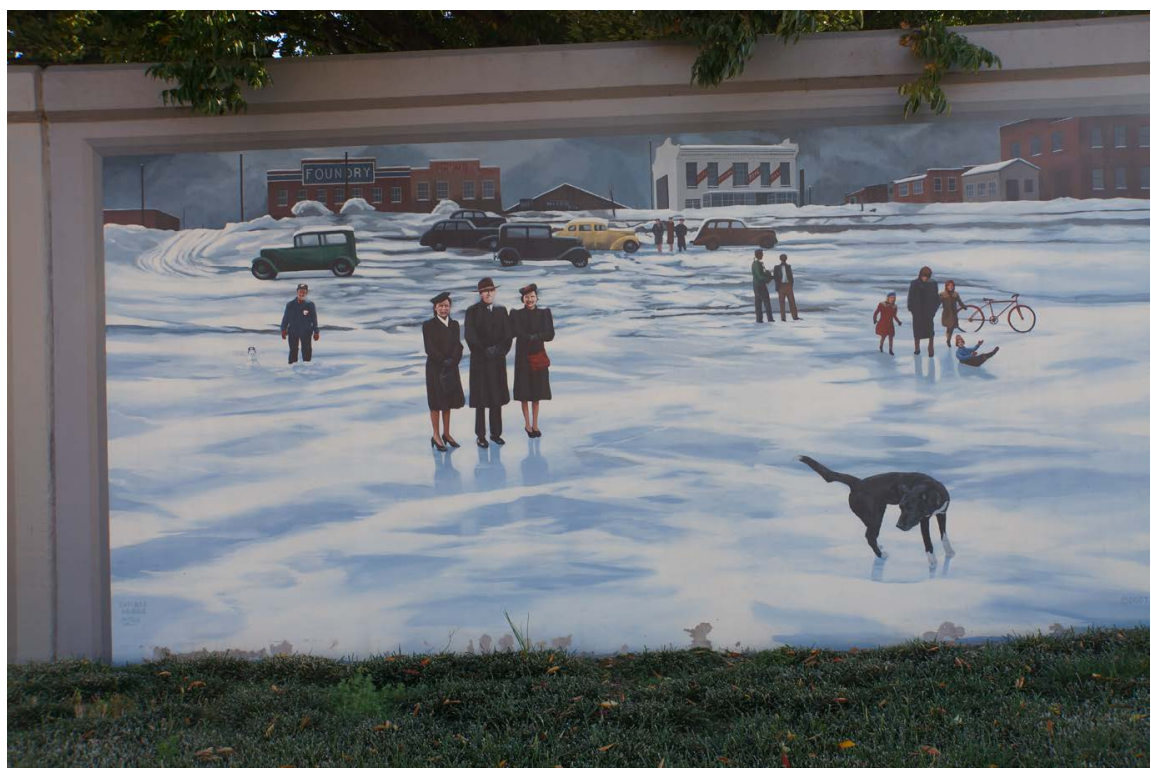

Figure 9. Robert Dafford floodwall mural depicting the frozen Ohio River in the winter of 1938. Photograph by Lois Wright Morton. 
River from draining into the Ohio River. Without an open outlet, the Tennessee River backed up and flooded surrounding river lowlands.

The Paducah gage on the Ohio River marked the crest at $18.4 \mathrm{~m}$ on February 2 , 1937. The river water stayed above flood stage until Feb. $15^{\text {th }}$. For 26 days, 27,000 residents who had been forced to flee Paducah had to stay with relatives and friends on higher ground in McCracken County and other adjacent counties. The local churches and the American Red Cross provided shelters for those who had no place to go. A total of $45 \mathrm{~cm}$ of rain over 16 days and sheets of moving ice on the rivers created the worst natural disaster in Paducah's history. Congress authorized the US Army Corps of Engineers (USACE) to build the current floodwall in 1938 ( $1 \mathrm{~m}$ above the 1937 record peak) to prevent future flooding of downtown businesses, industries, and residences. The floodwall had a series of movable gates that permit Steamboat passengers to walk through the floodwall to visit downtown Paducah (Figure 10).

\subsection{Tennessee Valley 1930 s and $1940 s$}

The 1937 flood was a disaster of unparalleled magnitude for Paducah and many other cities in the Ohio Valley and the lower Mississippi Valley. Over a million people were displaced, nearly 400 lives were lost and millions of dollars in damage to industries, businesses and communities were reported [4]. Although levees and floodwalls are critical infrastructure in protecting cities, industries and agricultural lands, the flood of 1937 demonstrated the need to control tributary and upstream runoff volume and velocity. Further, it became rather clear that the Ohio and Mississippi river basins were interconnected and needed a unified, comprehensive engineering and land use plan encompassing watershed and basin scales.

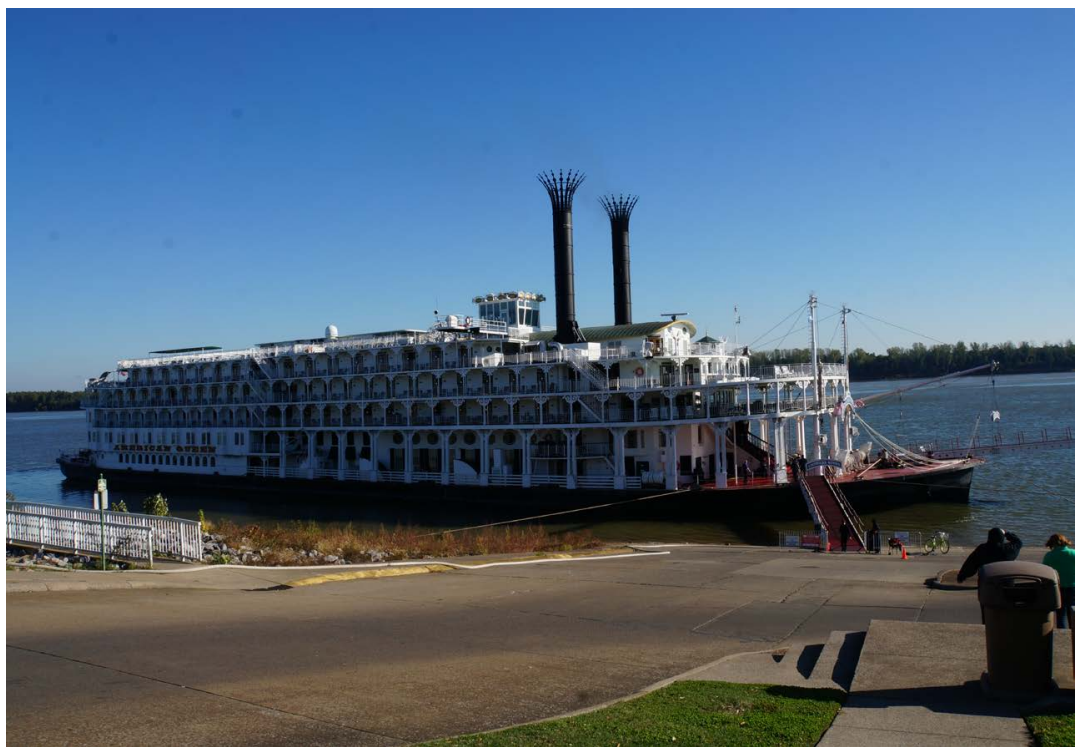

Figure 10. The Steamboat American Queen docked at Paducah, KY. Steamboat passengers are greeted by the Ambassador Club members each time they dock. Photograph by Lois Wright Morton. 
Eroded hillsides from years of poor cultivation practices (Figure 11) and depressed agricultural markets made it almost impossible for rural families to produce and sell enough agricultural products to meet their basic food and housing needs. During the 1800s timber and tobacco were main income sources in the Tennessee River Valley. However, by 1937 much of the land had been cultivated too intensively without good conservation practices resulting in eroded and depleted soil unable to produce sustainable crop yields (Figure 11). As agricultural yields declined so did farm incomes. Concurrently, the timber industry peaked and declined as the best of the hardwood forests had been clear cut. However, controlling main stem inland river flooding and tributary back flow were not the only problems facing central United States in the 1930s. Many rural areas lacked rural electricity, year around passable roads, and other public infrastructure. Malaria and yellow fever carried by mosquitos breeding in swamps and wetlands and cholera from contaminated drinking water caused illnesses and deaths. Rural poverty and joblessness were exacerbated by the Great Depression [4].

\subsection{Tennessee Valley Authority (TVA)}

In 1930s the country was in the Great Depression, President Roosevelt created the "New Deal" to help America recover. TVA was founded to help the hard hit Tennessee River Valley recover and improve the quality of life the people living in the valley. The TVA's mandate included controlling flooding on the wild Tennessee River. TVA's first task was to even out the flooding and drought extremes by building a system of dams and lakes to generate power, control flooding and create a system of water management for the greatest possible public good.

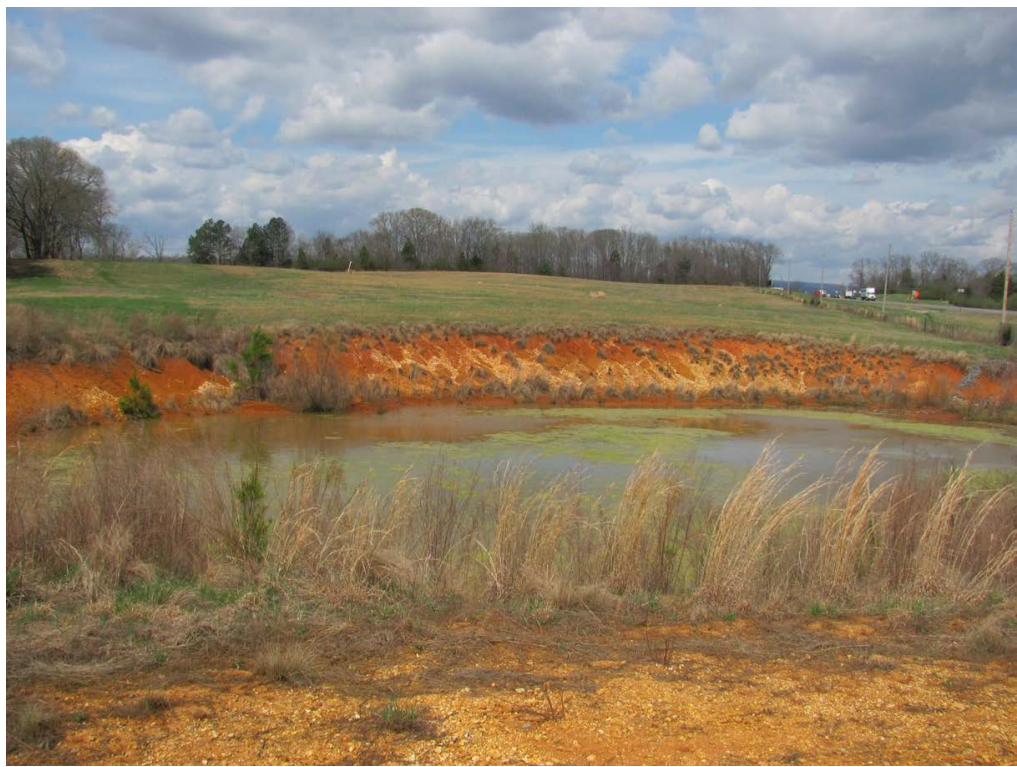

Figure 11. Red eroded soil since the soils contain hematite. Agricultural practices including row crops in the 1930s resulted in the loss topsoil and reduced productivity. 
Faced with a large portion of the U.S. population unemployed and unable to support themselves, President Franklin Roosevelt and Congress created a number of social, environmental, and economic government programs. Legislation in 1933 authorized the TVA, a public-private institution designed to produce low-cost electricity using hydropower and revitalize poor rural regions throughout the south. The largest public power provider in the United States, TVA served an area covering 207,200 $\mathrm{km}^{2}$ ranging from Tennessee, parts of Alabama, Kentucky, Georgia, and Mississippi to Virginia and North Carolina (Figure 2). During World War II, TVA hydropower produced electricity for critical war industries including aluminum plants that built bombs and airplanes. At its peak production in 1942, 12 steam plants and hydroelectric projects were under construction at the same time; and design and construction efforts employed 28,000 labors [7]. Today, TVA directly produces electricity for 56 industries and federal facilities and 155 local distributors who provide power to over 9 million people.

The first chairman of the TVA, Arthur Morgan, was an engineer with a vision for large scale, comprehensive planning that integrated building dam projects, public works employment and the transformation of poor rural communities in the Tennessee valley [8]. Morgan's social engineering and dam projects on the Miami River (Ohio) after the flood of 1918 offered a prototype for his problem-solving approach to address resource management and community development. The TVA attempted to balance social, economic, land use and natural resource management of the region in the development of electric power production, flood control, navigation, malaria prevention, erosion control reforestation, and employment. The TVA continues to operate on the principle of integrated solutions even as issues have changed over time.

TVA's River Forecast Center, located in Knoxville, Tennessee, is staffed 24 hours a day to monitor the river to control flooding and to provide water quality, availability and water demand data. In 1933, the TVA headquarters was required by a Congressional mandate to be created on the banks of the Tennessee River and not on a tributary, such as the Holston River [7]. For this reason, the headquarters was moved from Lenoir City to Knoxville and the confluence of French Broad and Holston Rivers.

Dam construction to harness the region's rivers was the cornerstone of the TVA (Figure 12). The dams controlled floods, generated electricity, improved navigation and provided jobs. Concurrent to building dams and rural electrification, TVA undertook rural development by teaching farmers erosion control practices to prevent soil loss and introducing fertilizers that improved crop yields. TVA also invested in the replanting of forests, better forest fire management, and preservation of wildlife habitat. Electricity generated by TVA dams (Figure 13) modernized rural farms and homes by providing electricity for lights, motors, and other power equipment.

\subsection{Construction of the Kentucky Dam on the Tennessee River}

One of the most powerful weapons for averting flood disasters and reducing the 


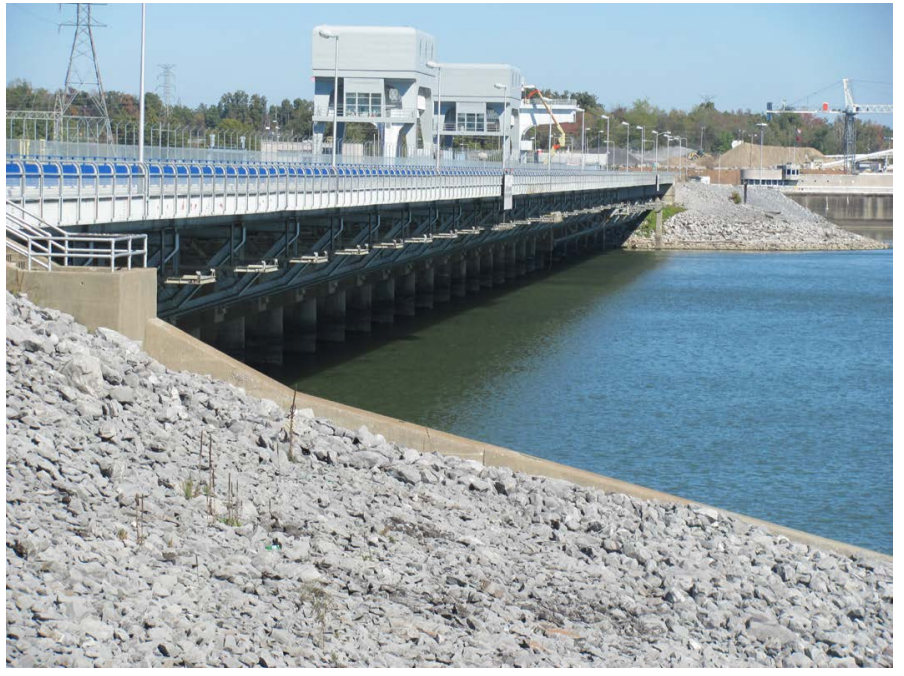

Figure 12. The Kentucky Dam at Gilbertsville, Kentucky was built on the Tennessee River $35 \mathrm{~km}$ upstream from its confluence with the Ohio River.

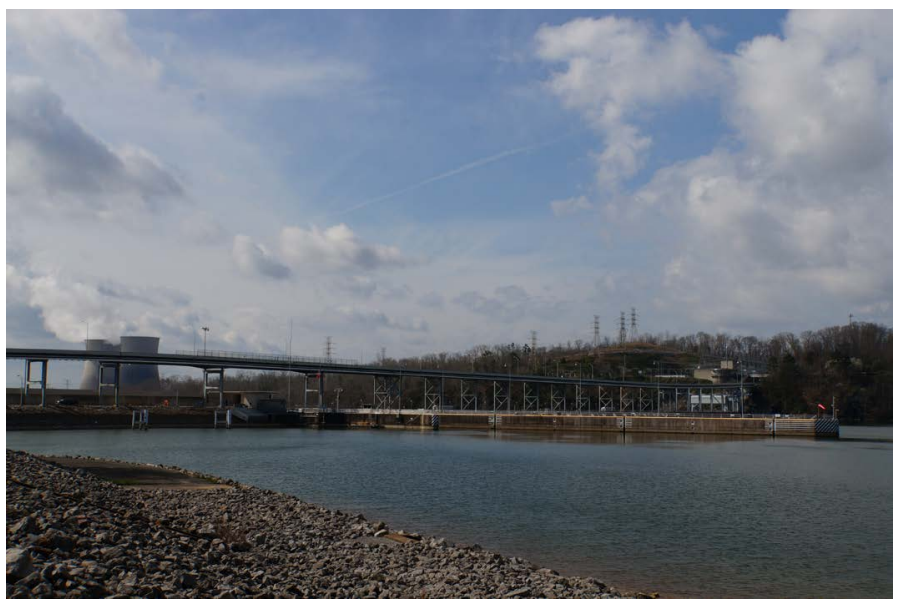

Figure 13. Watts Bar Dam on the Tennessee River between Knoxville and Chattanooga, Tennessee generates hydroelectricity, contributes to downstream flood management Two nuclear reactor cooling towers are visible in the background. Photograph by Lois Wright Morton.

maximum height of floodwater downstream is the network of reservoirs and dams built on tributaries hundreds of kilometers upstream in the headwaters of the Ohio and Mississippi river basins [4] [6]. The Kentucky Dam is on the Tennessee River (Figure 14) and $34 \mathrm{~km}$ upstream from Paducah and the Ohio River. The dam is one of the largest human constructed reservoirs built to store excess floodwater and produce electricity (Figure 15). In the late 1800s the most pressing inland river policy issues focused on encouraging industrialization, westward expansion and assuring navigation on the Ohio and Mississippi rivers [6]. Although high water was an expected seasonal occurrence, large flood events (Figure 16) only became a major concern as they collided with increasing settlement and industry development along river valleys. The disastrous flood of 1937 caused a number of United States politicians, engineers, and citizen leaders 


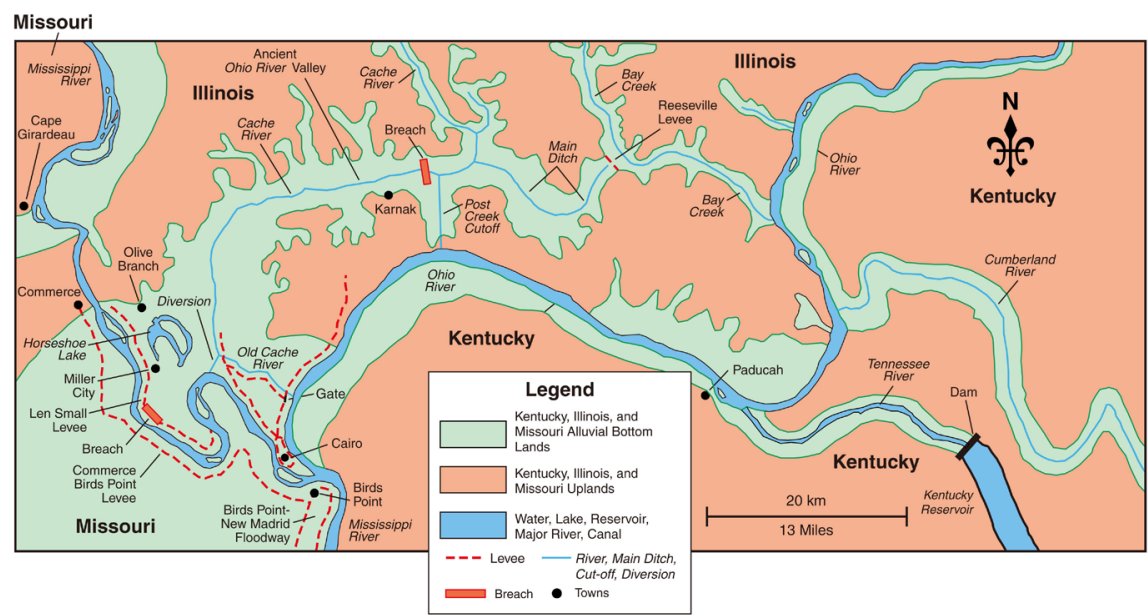

Figure 14. The Kentucky Dam and Lake on the Tennessee River, upstream from Paducah, control the release of water from the Tennessee River into the Ohio River. This reservoir can store excess floodwater or ensure sufficient downstream navigation depths during drought periods. Published with copyright permission from Book Editor of Soil and Water Conservation Society [3]. Map created by Mic Greenberg.

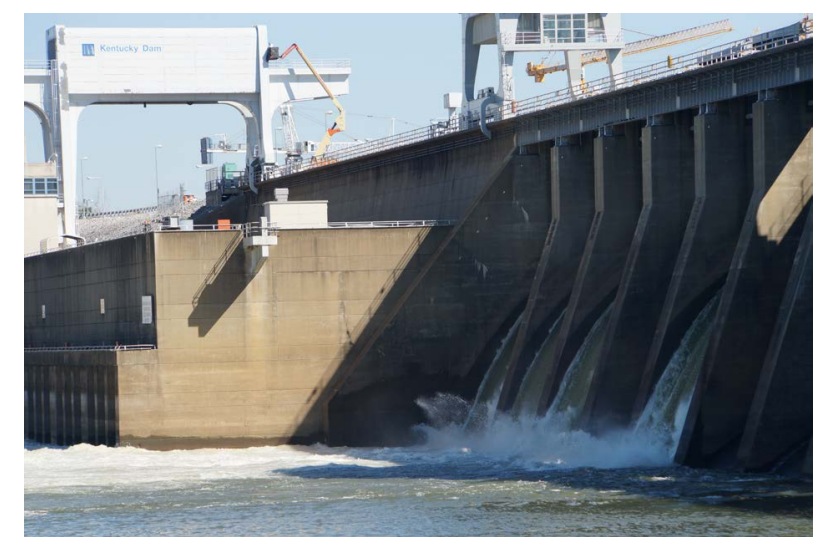

Figure 15. Kentucky Dam at Gilbertvillle, Kentucky was built on Tennessee River at mile marker 22. Photograph by Lois Wright Morton.

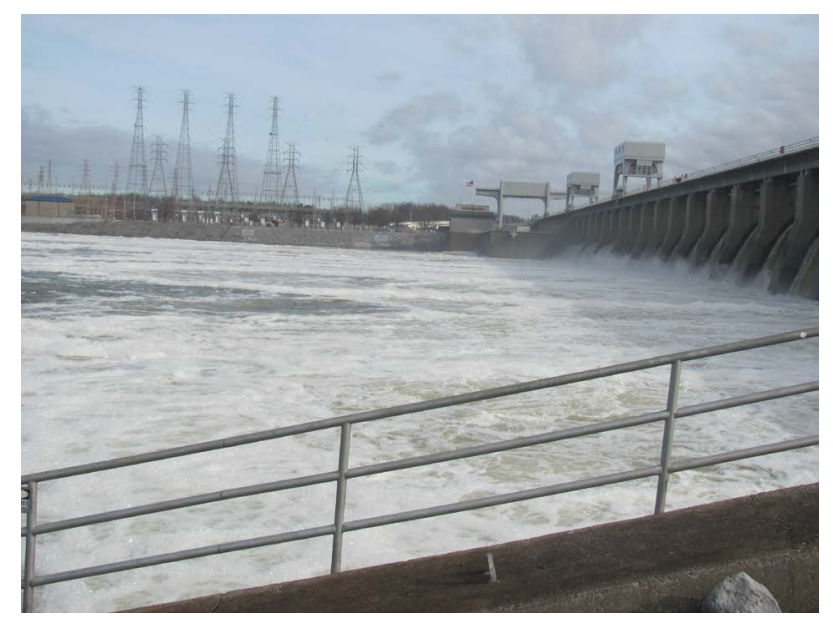

Figure 16. After a major winter flood peak pasted on the Ohio River the USACE release water from all the gages at the Kentucky Dam to the delight of local fisherman. 
to reimagine river basins as unique ecological units and to more purposefully manage them as watersheds. A 1908 report by the Inland Waterways Commission called for multipurpose dams, but it took another 30 years and a sequence major river flood disasters (1913, 1927, 1936-1937) before the Federal government, with public support, took leadership in constructing the system of dams and reservoirs we have today in the Ohio River basin [4] [5] [6].

During the 1937 flood, many communities along the Ohio River experienced water $4.5 \mathrm{~m}$ above previous records in their downtowns; loss of lives and property; disruptions to railroad traffic and the regional economy in the eastern half of the United States; and loss of telegraph connections and communication functions throughout much of the Ohio Valley. Paducah, Kentucky, at the confluence of the Tennessee and Ohio rivers, evacuated more than 27,000 of their 33,000 population [4] and lost most of their downtown. Paducah today is a thriving city which owes much of it character and revival to the painful destruction of its city in the 1937 flood. Its back-to-the-river renaissance now celebrates its river history with new industries, downtown redevelopment, riverfront stores and museums, and a floodwall which documents historical river events [6]. This spirit of recovery for Paducah is made possible by the $4 \mathrm{~m}$ floodwall (Figure 6) and 1940's construction of the Kentucky Dam (Figure 15) [7], a 294 km long reservoir which holds back and stores 494,378 hectare-m from the Tennessee River before releasing it into the Ohio River.

Upstream dam and reservoir construction is the most straight forward strategy for downstream flood protection. Dams hold back high volume runoff water from upland spring snow melt and extreme and prolonged periods of precipitation. This allows for the slow release of water downstream thereby managing river height and velocities and limiting potential flood damage. Five dams built in the early 1900's in the Miami Valley (Ohio) by a consortium of public and private interests withstood the 1937 flood in the Ohio River valley and demonstrated the effectiveness of river surveys, topographical maps, a network of gaging stations, and well sited reservoirs [4]. Lessons learned from the construction and management of these early dams provided the TVA with engineering and survey mapping knowledge and reaffirmed the value of comprehensive planning.

As early as 1920s and before the flood of 1937, area communities along the Tennessee River and their leaders lobbied Congress to have a dam constructed. The Kentucky Dam, a hydroelectric dam on the Tennessee River on the county line between Marshal County and Livingston County and within the state of Kentucky, was located in Gilbertsville after extensive geological and soil evaluation. The dam is $35 \mathrm{~km}$ above the mouth of the Tennessee River, which empties into the Ohio River at Paducah, Kentucky (Figure 2). After merging with the Tennessee River, the Ohio River flows another $74 \mathrm{~km}$ before draining into the Mississippi River at Cairo, Illinois. The Kentucky Dam (Figure 16), started in 1938 and completed in 1944, is the lowermost of nine dams including the Watts Bar lock and dam (Figure 17 and Figure 18) and the Fort Loudon lock and dam 
(Figure 19 and Figure 20) designed to hold back the Tennessee River. About 17 $\mathrm{m}$ above the original river, the dam controls the release of water into the Ohio River and helps manage the fast rise of the Ohio and Lower Mississippi Rivers during spring snow melt and rains.

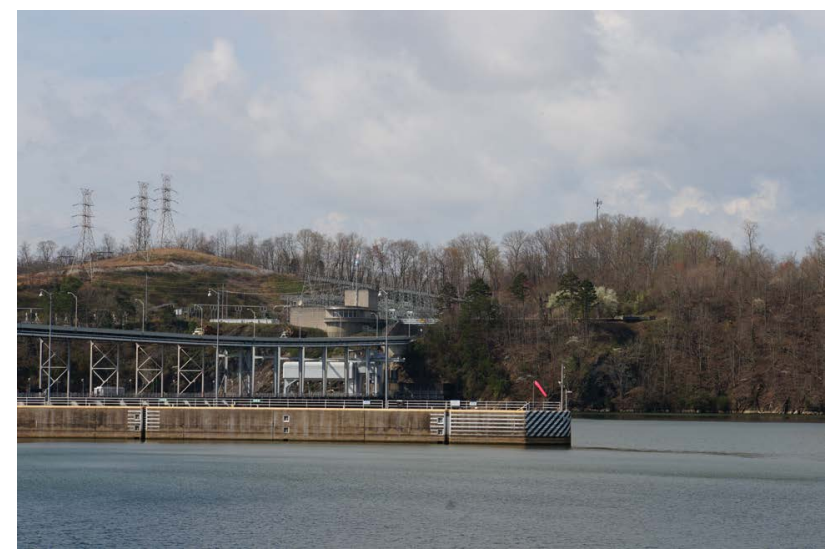

Figure 17. The Watts Bar Dam on the Tennessee River between Knoxville and Chattanooga, Tennessee. Photograph by Lois Wright Morton.

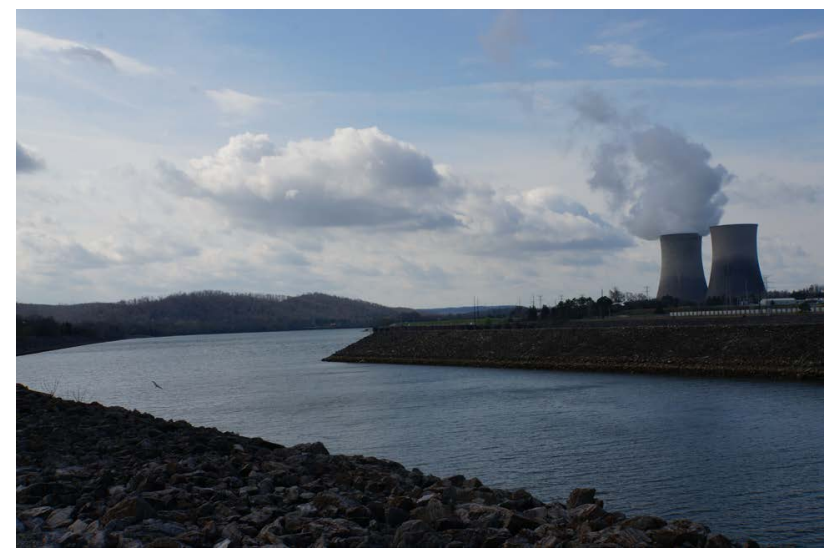

Figure 18. Two Watts Bar nuclear reactor cooling towers are on the Tennessee River. Photograph by Lois Wright Morton.

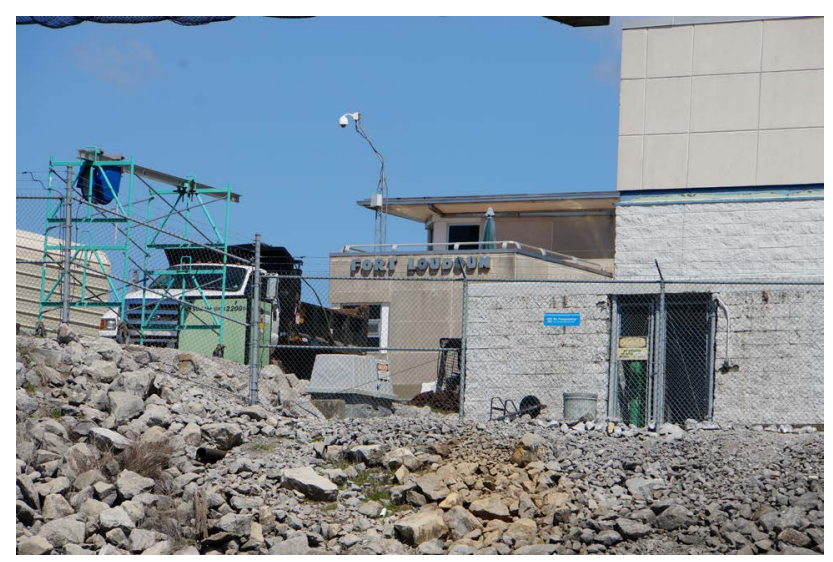

Figure 19. Fort Loudon locks and gates enables navigation on the Tennessee River via its locking system. Photograph by Lois Wright Morton. 


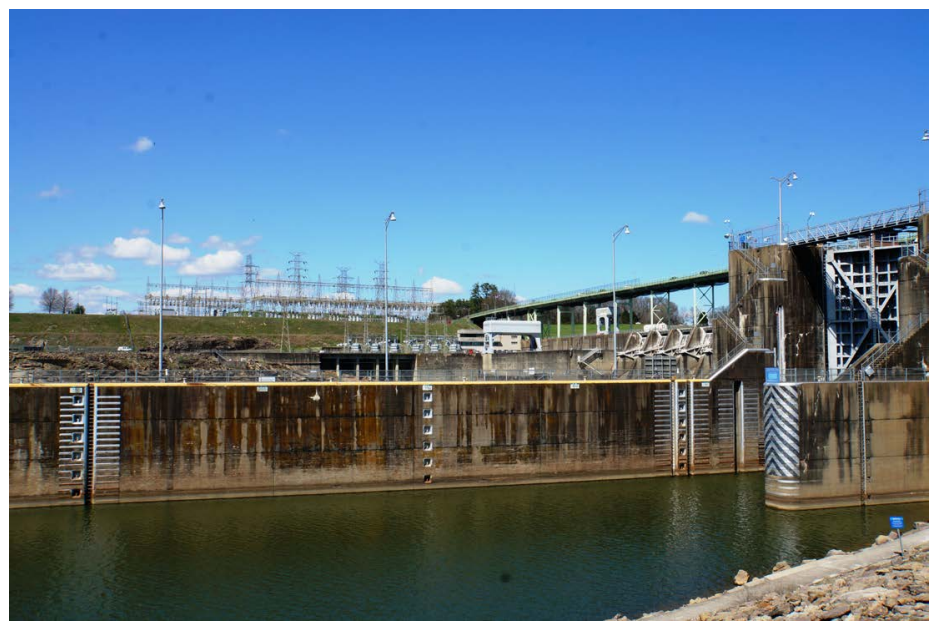

Figure 20. Fort Loudon Dam generates hydroelectricity. Photograph by Lois Wright Morton

The Kentucky Dam at $63 \mathrm{~m}$ high and $2567 \mathrm{~m}$ long is the widest dam (Figure 21) on the Tennessee River and in the TVA system. The dam impounds Kentucky Lake which covers 65,000 ha; making it the largest of the TVA reservoirs by area and the largest artificial lake in eastern United States. Kentucky Lake has $3322 \mathrm{~km}$ of shoreline and the most flood storage capacity, $4944 \mathrm{Gl}$ of any lake in the TVA system.

The construction of Kentucky Dam and its reservoir resulted in the public purchase of 129,598 ha of land including 19,625 ha of forest, which had to be cleared. Prior to the flooding of the land to create the reservoir, over 3390 graves, 2600 families, and $587 \mathrm{~km}$ of roads had to be relocated. Bridges over some roads needed to be rebuilt and sixty-five new ones were constructed on the new roads. The Illinois Central Railroad was rerouted to cross the top of the Kentucky Dam (Figure 22). Several small communities were submerged by the new reservoir and a dike was constructed around Big Sandy, Tennessee to protect the town from reservoir backwater [8]. Kentucky Dam, located in the New Madrid Seismic Zone, was built to withstand 7.0 - 7.9 magnitude earthquakes. Construction was finished on August 30, 1944, at a cost of nearly $\$ 118$ million [8].

Railroads relocated include the Illinois Central (now Louisville \& Paducah) railroad and the now abandoned Louisville \& Nashville railroad. During WWII, the United States needed to build aluminum bombs and airplanes, and plants required electricity. To provide electricity for such critical war industries, the TVA created one of the largest hydropower construction programs ever undertaken in United States. Early in 1942, when the construction reached its peak, 12 hydroelectric projects and steam plants were being built at the same time with the design and construction activities employing 28,000 people. Public funding of the Tennessee Valley Authority power program ended in 1959 and its environmental and economic development activities were phased out by 1999 [8]. Electricity sales and other power initiatives currently fully fund all the TVA's activities. 


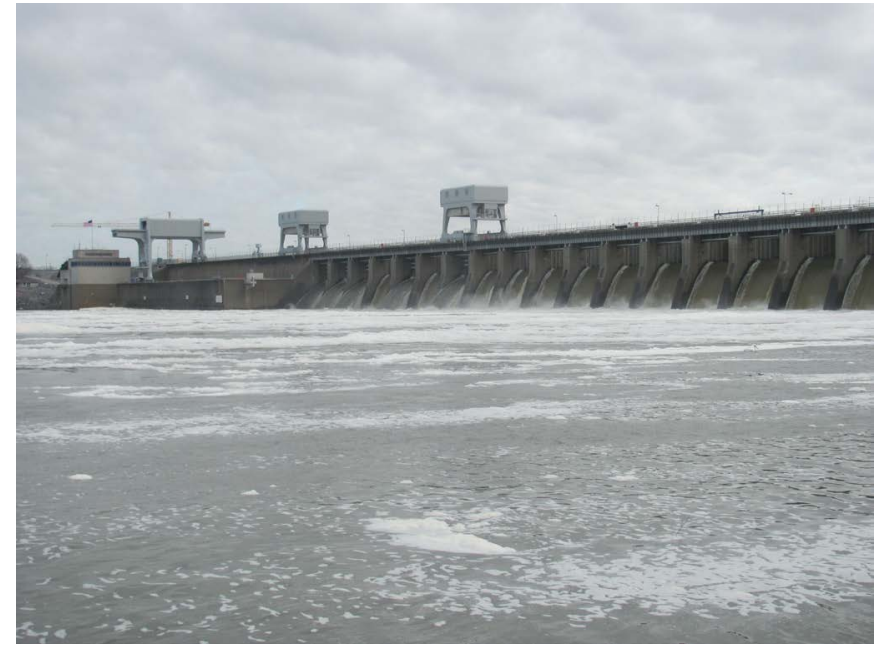

Figure 21. Kentucky Dam wide with gates open to reduce the flood pool on the Tennessee River after a major flood on the Ohio River.

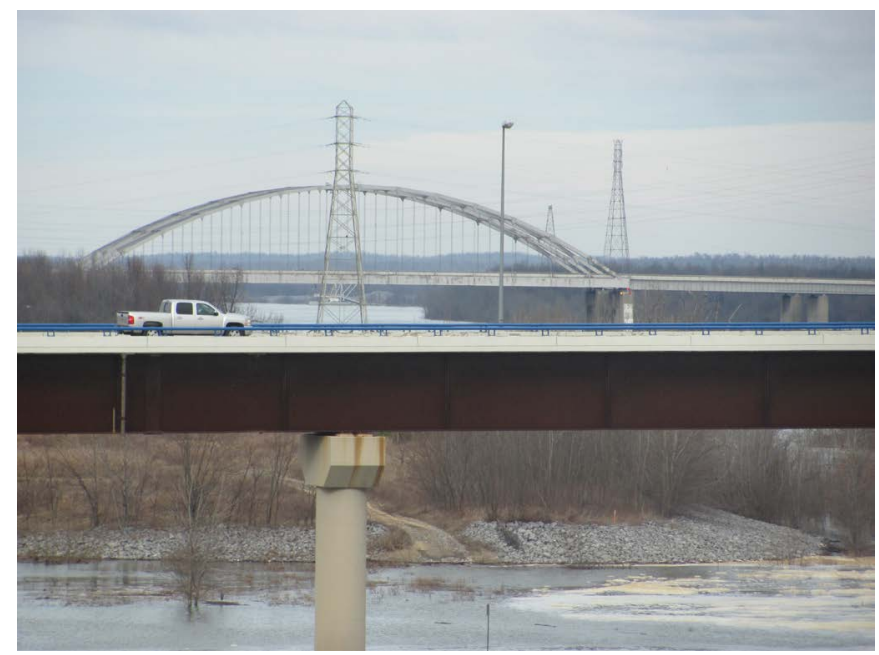

Figure 22. Kentucky Dam and railroad bridge just north of the highway and the lock and dam.

\subsection{Navigation on the Tennessee River}

By the end of the WWII, TVA had created system of dams and locks on the 1005 $\mathrm{km}$ long Tennessee River navigation channel. The locks and dams have a significant impact on the economy of the region. Historically, goods were shipped by rail or truck. The use of barges reduced shipping cost by about $\$ 500$ million each year depending on volume and year [9]. The railroads reduced shipping costs to stay competitive with barge transport. This meant lower prices and costs for consumers. One 15 barge tow can carry the same amount of freight as 216 rail cars and six locomotives or 1050 large semi-trucks [10]. Water transportation reduces labor costs, highway traffic, air pollution, fuel consumption, highway maintenance and the number of tires placed in landfills.

The Tennessee River originates at Knoxville, Tennessee (Figure 1) and drops $156 \mathrm{~m}$ before it joins the Ohio River at Paducah, Kentucky. Much like the Ohio 
River prior to the construction of the lock and dam system, the Tennessee River depth had a great deal of variability. Shoals and rapids made navigation almost impossible depending on drought, seasonal rainfall and timing of snowmelt. The Tennessee River has nine main-river locks and dams (Figure 17 and Figure 20) which create a continuous series of pools the length of the Tennessee River and enable navigation. River navigation is possible from Knoxville, up river on the Ohio River to Pittsburgh, Pennsylvania (Figure 23), or downstream to the Ohio-Mississippi river confluence at Cairo, Illinois (Figure 24) and south to the Gulf of Mexico (Figure 25). Commercial navigation occurs on three major tributaries of the Tennessee: up the Cinch River $98 \mathrm{~km}$; up the Little Tennessee $46.7 \mathrm{~km}$; and up the Hiwassee River $35 \mathrm{~km}$. Recreational boating is popular on

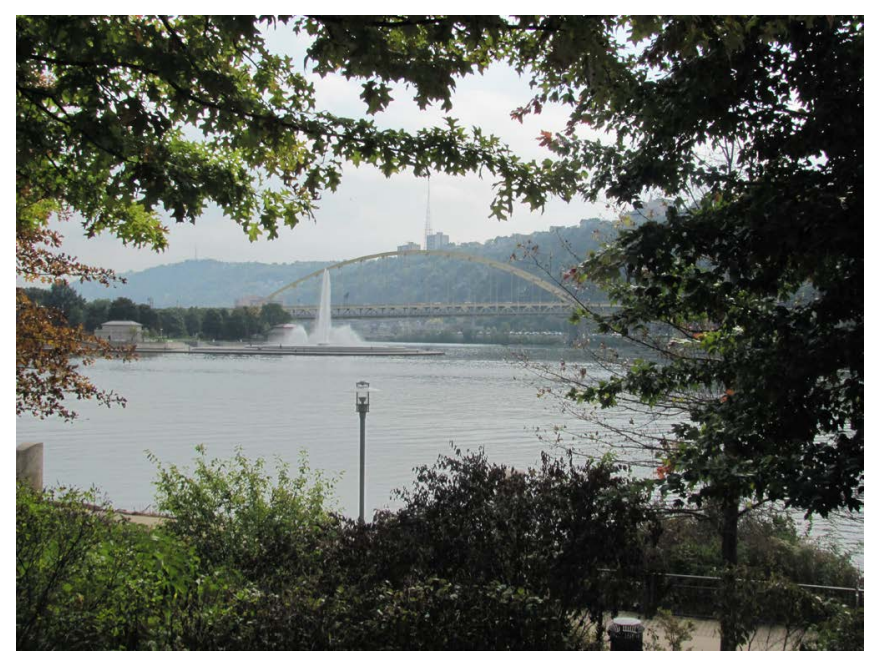

Figure 23. The confluence of the Allegheny (left) and Mongahela (right) rivers in downtown Pittsburgh, Pennsylvania, forms the beginning of the Ohio River, a major tributary of the Mississippi River. Photograph by Lois Wright Morton.

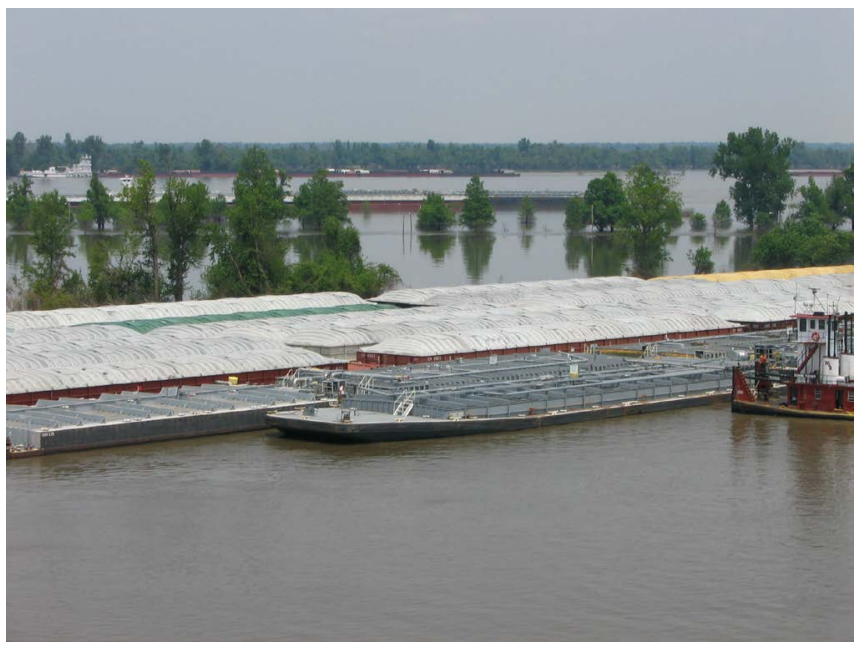

Figure 24. Fort Defiance State Park, the southernmost point of Illinois, was under water most of the spring of 2011, with only treetops visible. The park is located outside the Cairo levee and floodwall system at the confluence of the Ohio (top of picture) and Mississippi (bottom of the picture) rivers. 


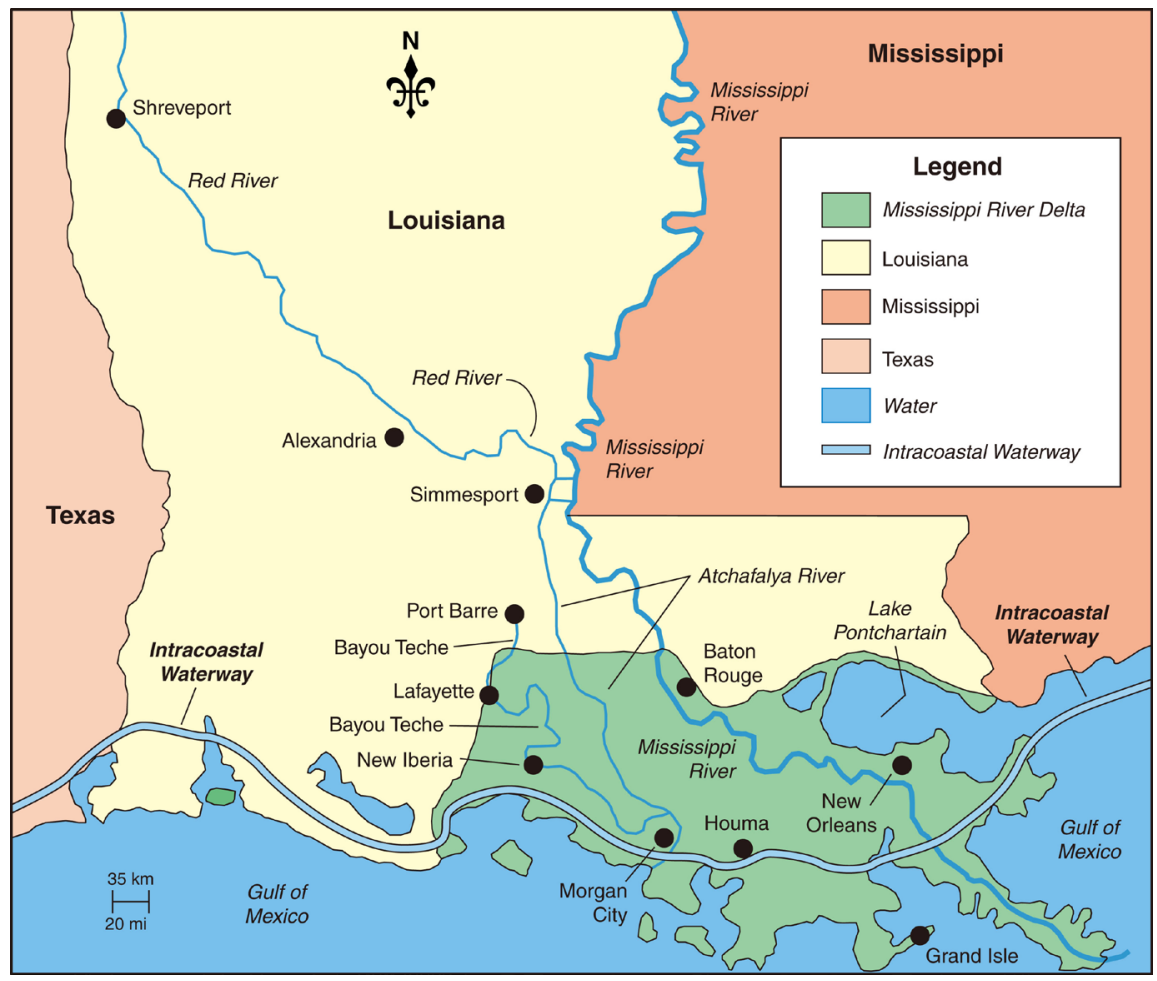

Figure 25. Gulf of Mexico and the Mississippi River delta. The Mississippi River extends just north or upriver from Baton Rouge, Louisiana the Capital of Louisiana. Map created by Mic Greenberg.

the river and over 13,000 recreational craft annually lock through the system. In addition to the $2.74 \mathrm{~m}$ channel commercial vessels use, about $600 \mathrm{~km}$ can be used by recreational boaters but are too shallow for commercial traffic. River ports have become regional centers of social and economic vitality and sources of industrial activity. River transportation of food products for processing has proved to be inexpensive and efficient, reducing the price of groceries in the Southeast and across the United States.

\subsection{Ecological Impacts of Changes to the Tennessee River LandScape}

TVA dam construction on the Tennessee river and tributaries has re-aligned the river flow patterns, temperatures and sediment transport thereby modifying aquatic and terrestrial habitats [9] [11] [12]. Hydropower demands resulted in timed water releases to meet power production needs without regard to aquatic ecosystem impacts. Consequently, water depth and velocities in tail waters below the dam before it flows into the next reservoir during non-generation periods declined to very low levels. Further, reservoir conditions and the dam structure produced low dissolved oxygen (DO) concentrations the low tail waters exacerbating the aquatic ecosystem conditions [11]. In 1991, TVA put in place a Reservoir Releases Improvement Plan to address deteriorating ecological conditions in the Tennessee watershed. Modifications included the installation of fish 
ladders and experiments in adding DO and changing the minimum flow to tail waters by modifying timing, velocity, and quantity of periodic water releases. A variety of strategies are used to increase DO including pumps, turbine venting, air blowers, forced air turbine venting, infuser weirs, and line diffusers [11].

A number of studies have begun to monitor dam modifications and impacts on abiotic and biotic conditions and the abundance and diversity of fish species to better understand the extent to which these modifications mitigate and restore the ecology of the river. Of particular interest are changes in discharge fluctuations into tail waters associated with peaking hydropower operations. Monitoring data below nine dams showed yearly and mean minimum velocity and mean DO increased following dam modifications. Flow changes alone had a smaller benefit than the combined effects of increased flow and increased DO [11].

The Cumberland and Tennessee river basins-considered a single aquatic ecoregion-contains one of the most diverse temperate freshwater species in the North America, including 231 fish species, mussels, crayfish, and salamanders [9]. However, urbanization, mining, logging, agriculture, river channelization and dams have accelerated erosion and sedimentation, changed stream flows, and degraded or destroyed aquatic habitat putting many of these species at risk. Research on ecological flows of the Tennessee River and their tributaries [9] is examining how changes in climate, land cover, soil properties and physiography drive stream flow responses. Knight et al. [9] found basin characteristics explained over half of the variation in streamflow with daily temperature range, rock depth and geology being other co-variables. One of the most influential factors is regional climate variables-mean monthly precipitation, daily temperature range, January precipitation, and August temperature. The relationship between flow and aquatic ecology is complex and not yet well understood [12]. The TVA continues to monitor and use research findings as feedback loops to adaptively manage not only their lock and dam network but also the land and river uses throughout the Tennessee River basin.

\subsection{Bighead and Silver Carp in the Tennessee River Have Invaded Kentucky Lake in Substantial Numbers}

The silver carp (Hypophthalmichthys molitrix) (Figure 26), also known as the flying Asian carp [10], began migrating through the Mississippi River, Ohio River and into the Tennessee River and have now enter both the Kentucky and Barkley Lakes [12]. The carp escaped the Arkansas fish farms and began migrated up the Mississippi River system. The carp can jump above water and can grow to $23 \mathrm{~kg}$. The carp were first introduced, with the approval of the Environmental Protection Agency (EPA) in the 1970s, to help consume algae in catfish farm ponds within Arkansas [12]. The carp remove the bottom of the food chain for indigenous species and displace the native species of filter feeding fish. Harvesting the carp for food has been one of the most successful approaches to date (Figure 27). 


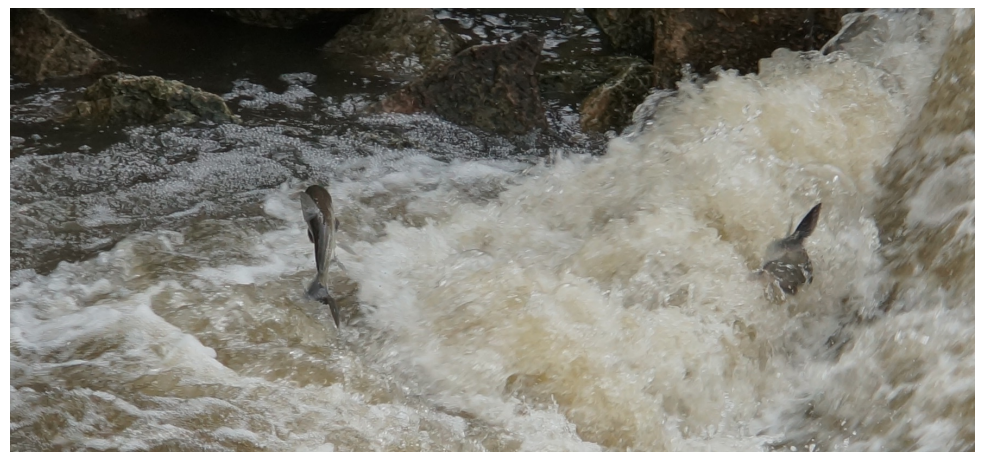

Figure 26. Flying Asian carp jumping out of the water to travel upstream on Mississippi and Ohio River tributaries including the Tennessee River.

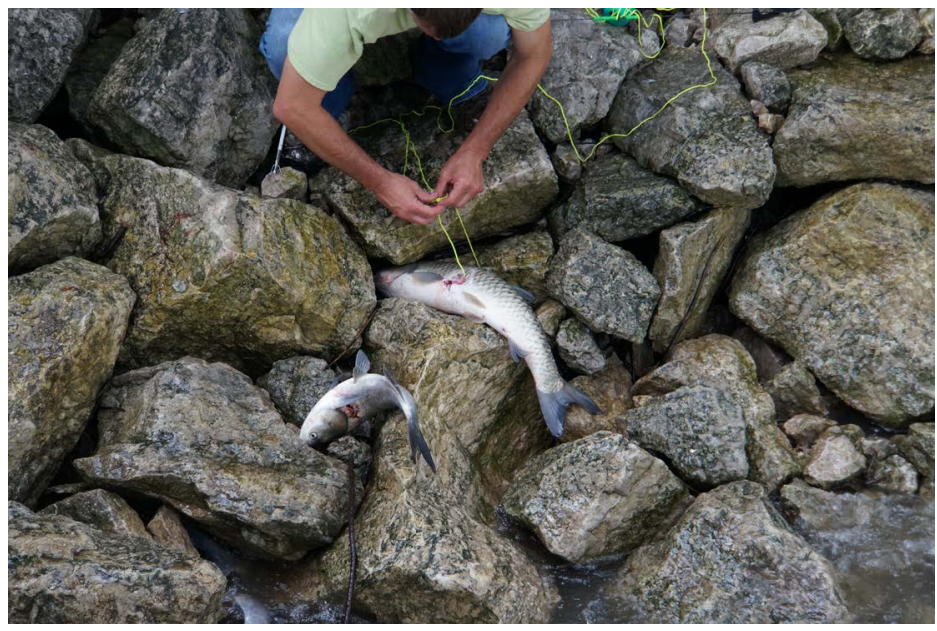

Figure 27. Asian carp being harvest by local fisherman. One of the best methods of reducing the Asian carp is to over fish the Tennessee River and tributaries.

There are several kinds of Asian carp that have spread (or are spreading) around North America, and the two that have garnered the most attention at present are the bighead carp (Hypophthalmichthys nobilis) and silver carp and (personal communication, Dr. Cory David Suski, NRES, ACES, UIUC) [12]. Dr. Suski suggested "the carp do not displace native fishes and he is not aware of any displacement to date". Dr. Suski noted "that the Asian carp out-compete the native fish for food, and several species of fishes (particularly filter feeding fishes) have experienced reduced conditions, likely through competition" [13]. There are other carps (grass carp, black carp) but of less concern than bighead and silver carp.

\subsection{Tennessee River Regional Trail System}

Known as North America's Next Regional Trail System, the Tennessee River Line project [14] was started in 2016 and headquartered in Knoxville, Tennessee. The School of Landscape Architecture at the University of Tennessee's College of Architecture and Design started work on the concept in 2016. The pilot program was set up at five sites in 2019 (Figure 6). The program included efforts to 
create more access points from the water into communities from Paducah, Kentucky to Knoxville, Tennessee. The potential for economic development and recreational tourism is huge. There are 48 million ha of public parklands (Figure 28 and Figure 29) along the Tennessee River pathway. The next phase, a River Towns program has the potential to link communities via the River Trails program. The River Line Partnership now has the support of Tennessee Valley Authority, the River Discovery Center of Paducah and the National Parks, marinas (Figure 30) and other conservation and environment groups such as The Nature Conservancy.

"The Tennessee River Line trail project was started to create a network of trails to paddle, hike and bike along the 652 river mile length of the Tennessee River. The project is now taking the next step, by signing the first batch of River Towns to participate in the project" [14]. The Tennessee River Line trail project

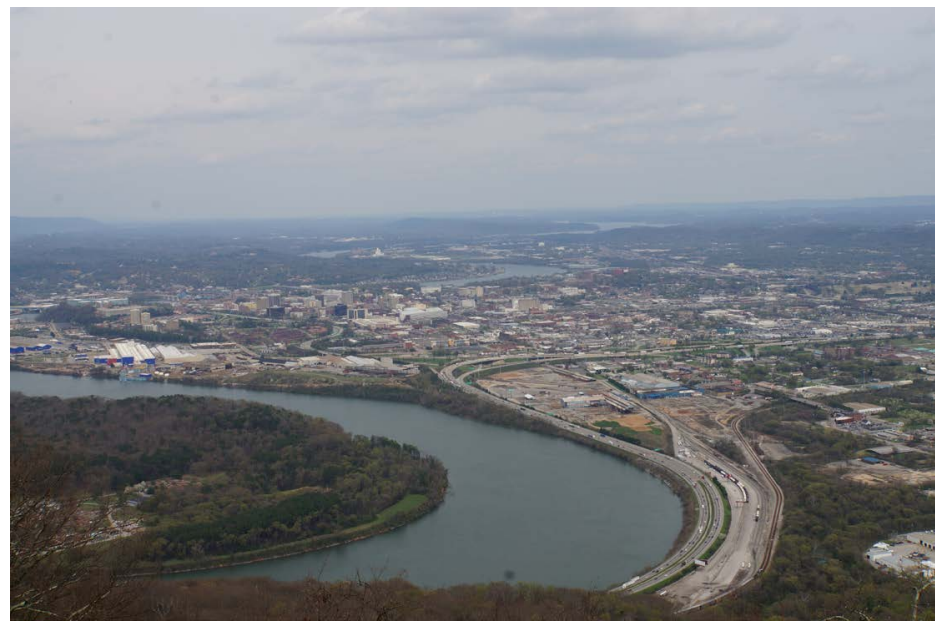

Figure 28. Parkland south of Chattanooga and Tennessee River and viewed from on Lookout Mountain. Photograph by Lois Wright Morton.

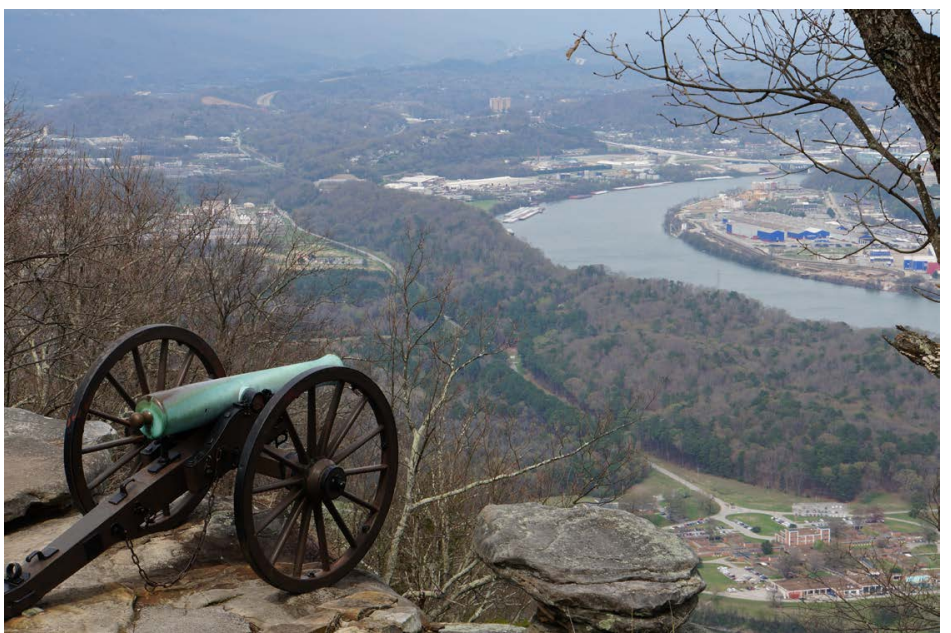

Figure 29. Lookout mountain and canon civil war used by the Southern forces to defend the mountain from an attack by the Northern forces via the Tennessee River. Photograph by Lois Wright Morton. 
which started in Knoxville is now "Flowing" to Alabama, Mississippi and Kentucky with ready to sign up for the River Towns program. The first batch of River Towns were announced on October 23 of 2020. The inaugural cohort of Tennessee River Towns program included both Paducah-McCracken County (Figure 31 and Figure 32) and Calvert City in the group of 15 communities selected.

The River Line Partnership is a "generational project" created to increase recreational usage of the Tennessee River and watershed. The program goal is to create generations of people who care about the river and provide the environmental stewardship for its protection.

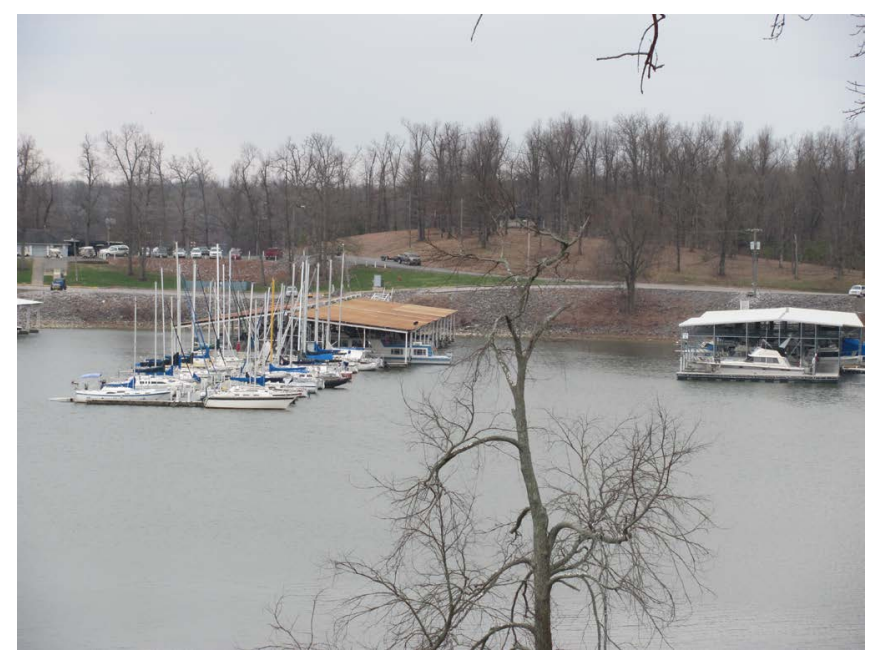

Figure 30. A shoreline and marina on Kentucky Lake adjacent to Kentucky Dam lodge.

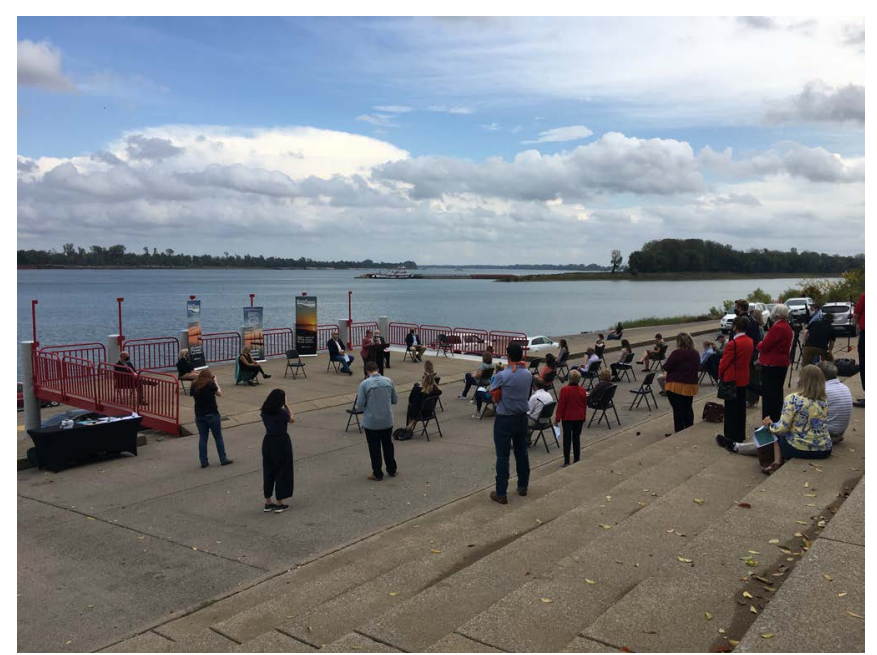

Figure 31. The October 23, 2020 Tennessee RiverTowns ceremony and socially distant crowd at Paducah floodwall. From left to right: Paducah City Manager Jim Arndt, Paducah Commissioner Sandra Wilson, River Discovery Executive Director Julie Harris, McCracken County Judge Executive Craig Climer, Calvert City Mayor Lynn Jones and Tennessee RiverLine 652 Project Director Brad Collett. At the podium is Mayor Brandi Harless. Picture was taken by Pam Spencer, Communications Manager for the City of Paducah. 


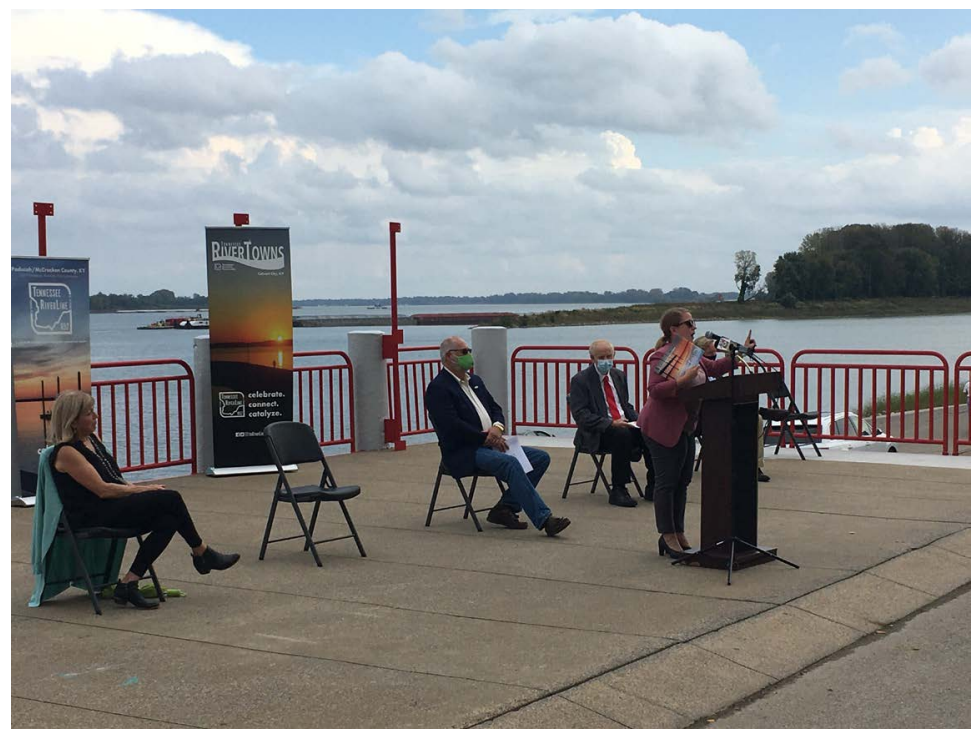

Figure 32. Close-up of the October 23, 2020 Tennessee RiverTowns ceremony with Paducah Mayor Brandi Harless at Wilson Stage podium along the Ohio River floodwall at Paducah and west of the confluence of the Tennessee and Ohio Rivers. Picture was taken by Pam Spencer, Communications Manager for the City of Paducah.

\section{Conclusions}

The Tennessee River and its series of locks and dams are owned by the U.S. federal government and jointly managed by TVA and USACE. The U.S. Coast Guard (Figure 33) works closely with both agencies to assure reliable and safe navigation for commercial and recreation vessels and enforces maritime laws, marine safety and investigations of marine accidents [15]. The Coast Guard is also responsible for installation and maintenance of lights, buoys, and shoreline markers along $1280 \mathrm{~km}$ of the river's commercial channel.

With the construction of the Kentucky Dam on the Tennessee River water can be stored and released during droughts to maintain a minimum $2 \mathrm{~m}$ depth of water above the $2.7 \mathrm{~m}$ shipping channel. These water releases also increase the water level in the lower Mississippi River. During the 2012 drought, the USACE was able to add $1.2 \mathrm{~m}$ to the existing river water level which reduced the need for dredging. During major flooding events, between 1940s and 2011, the New Madrid floodway in Missouri did not have to be opened until 2011. The USACE was able to mitigate the flood impact by not releasing water from upstream reservoirs including the Kentucky Lake.

This strategy worked until the record flood of 2011 when the Kentucky (built in 1940s) and Barkley (Figure 34) (built in 1960s) dams and reservoirs [3] were not able to hold any more floodwater and had to release some into the Ohio River, contributing to the record peak at the confluence of the Mississippi and Ohio rivers. Without the use of the Kentucky reservoir and later the Barkley reservoir on the Cumberland to manage peak flow, the New Madrid floodway would have had to be opened during major flooding events between the 1940s and 2011 and with substantive soil and crop damages to would have occurred. 


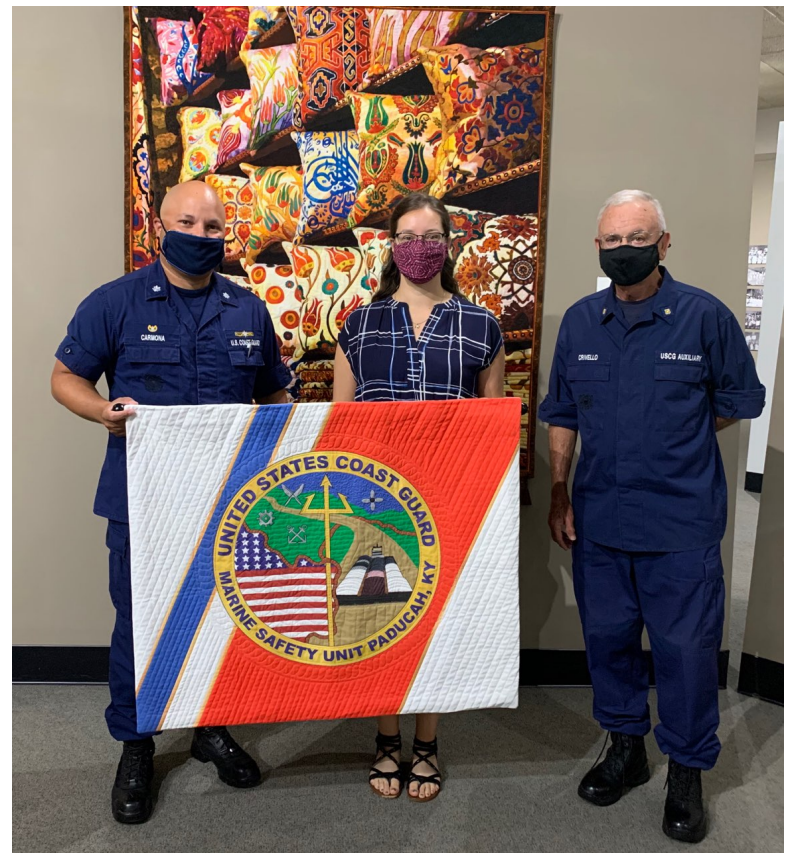

Figure 33. U.S. Coast Guard Commander Luis O. Carmona, Quilt Artist Rebecca Glasby, Coast Guard Auxiliary member John Crivello with the Marine Safety Unit, Paducah logo quilt. Picture was taken in front of a display quilt at the National Quilt Museum. Picture was taken by U.S. Coast Guard MSTI William Battle.

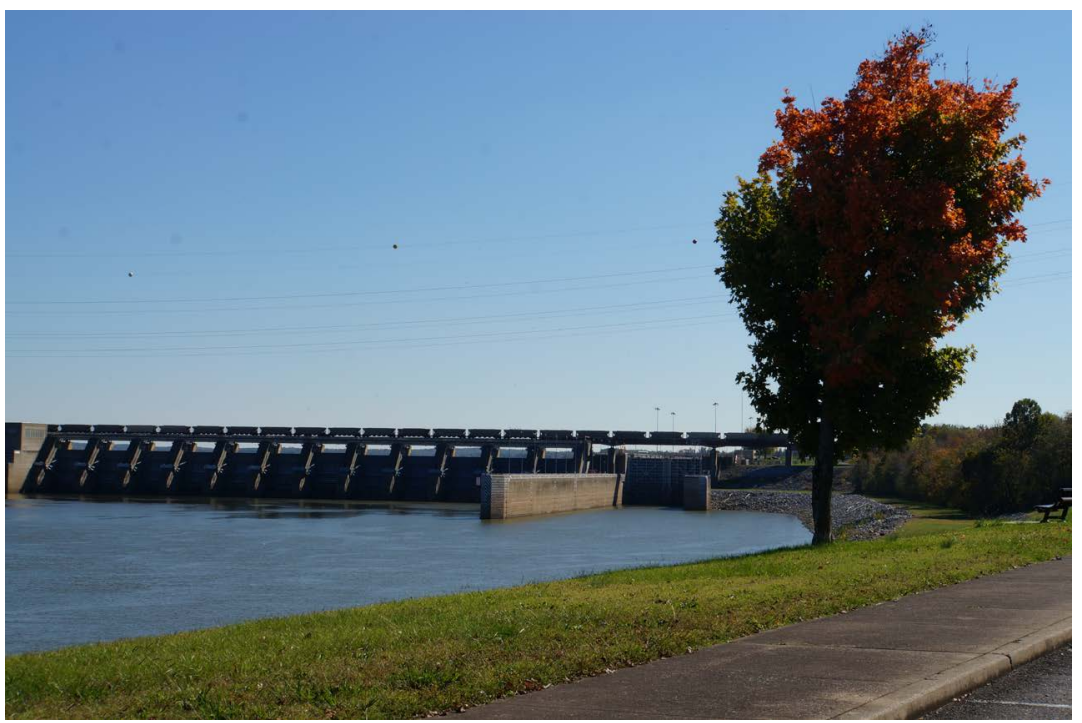

Figure 34. The railroad built above the Barkley Lock and Dam on the Cumberland River Barkley Dam and train. Photograph by Lois Wright Morton.

\section{Acknowledgements}

Published with funding support from USDA, NIFA, Water Division and the Department of Natural Resources and with the approval of the Director of the Illinois Office of Research, College of Agricultural, Consumer, and Environmental Science, University of Illinois, Urbana, Illinois. The author wants to thank John and Cindy Crivello, members of the Paducah Ambassador Club, who provided 
pictures, suggested topics, edited and fact-checked the manuscript.

\section{Conflicts of Interest}

The author declares no conflicts of interest regarding the publication of this paper.

\section{References}

[1] Golden Pond (2014) Visitor Center Land between the Lakes National Recreation Area Exhibits.

[2] Wikipedia (2020) The Tennessee River. The Free Encyclopedia: Wikimedia Foundation, San Francisco.

[3] Olson, K.R. and Morton, L.W. (2016) Managing the Mississippi and Ohio River Landscapes. Book Division, Soil and Water Conservation Society, Ankeny.

[4] Castro, J.E. (2009) The Great Ohio River Flood of 1937. Arcadia Publishing, Charleston.

[5] Morton, L.W. and Olson, K.R. (2019) Securing the Nation's Infrastructure: The Ohio River. Journal of Soil and Water Conservation, 74, 5-11. https://doi.org/10.2489/jswc.74.1.5A

[6] Welky, D. (2011) The Thousand-Year Flood: The Ohio-Mississippi Disaster of 1937. University of Chicago Press, Chicago. https://doi.org/10.7208/chicago/9780226887180.001.0001

[7] Tennessee Valley Authority (1951) The Kentucky Project: A Comprehensive Report on Planning, Design, Construction and Initial Operations of the Kentucky Project. Tech Report, United States Government Publishing Office, Washington DC.

[8] TVA. Tennessee Valley Authority (2015). http://www.tva.gov/heritage/visionary/index.htm

[9] Knight, R.D., Gain, W.S. and Wolfe, W.J. (2012) Modelling Ecological Flow Regime: An Example from the Tennessee and Cumberland River Basins. Ecohydrology, 5, 613-627. https://doi.org/10.1002/eco.246

[10] Hette, M. (2020) DOT Webinar Focuses on Inland Waterways Use, Maintenance and Needs. The Waterways Journal, 134, 22.

[11] Bednarek, A.T. and Hart, D.D. (2005) Modifying Dam Operations to Restore Rivers: Ecological Responses to Tennessee River Dam Mitigation. Ecological Applications, 15, 997-1008. https://doi.org/10.1890/04-0586

[12] McManamay, R.A., Orth, D.J., Dolloff, C.A. and Mathews, D.C. (2013) Application of the ELOHA Framework to Regulated Rivers in the Upper Tennessee River Basin: A Case Study. Environmental Management, 51, 1210-1235. https://doi.org/10.1007/s00267-013-0055-3

[13] Matheny, J. (2020) Tennessee River Line Trail Project Takes Next Step with RiverTowns. 10News, Knoxville.

[14] Olson, K.R. and Morton, L.W. (2017) Chicago's 132-Year Effort to Provide Safe Drinking Water. Journal of Soil and Water Conservation, 72, 19-25. https://doi.org/10.2489/jswc.72.2.19A

[15] Olson, K.R. and Morton, L.W. (2014) Runaway Barges Damage Marseilles Lock and Dam during 2013 Flood on the Illinois River. Journal of Soil and Water Conservation, 69, 104-109. https://doi.org/10.2489/jswc.69.4.104A 